\title{
AFRICAN INDIGENOUS CHURCHES (AICs) AND DEVELOPMENT
}

\author{
J J KRITZINGER
}

\begin{abstract}
Development is one of the most important topics for discussion and action in the Third World. It is however an extremely controversial subject. Taking as point of departure the nowadays generally accepted notion that all development must actually benefit the people concerned in a wholistic way, this article attempts to contribute to the discussion by criticising some general notions and indicating some of the pitfalls in development thinking.

Some researchers of the African Indigenous Churches (among whom are Daneel, Oosthuizen and Turner) have already alluded to the impact that these movements have on the socio-economic advancement of their members in particular, and society in general. The present article enters into dialogue with these writers in the light of the wider discussion on development issues.
\end{abstract}

\section{Introduction}

At the New ERA Conference held around New Year 1984 in Puerto Rico, the intrepid researcher of New Religious Movements in the Third World, Harold W Turner, read a paper on "The relationship between development and New Religious Movements in the tribal societies of the Third World"1" 1 will take Turner's thoughts as point of departure by giving a brief overview, and adding some tentative notes which I would like to return to further on.

Apart from Turner, our well known Professor Gerhardus C Oosthuizen, presently head of the Research Unit on New Religious Movements and Independent/Indigenous Churches (NERMIC), made an equally important contribution in a paper called "Africa's social and cultural heritage in a new era", read on the 4th of October 1985 at the Silver Jubilee Conference of the Africa Institute. ${ }^{2}$ In this paper he investigated the extent to which the African heritage is enhancing or retarding Africa's development. Three years later he again dealt with the topic "Religion, its negative and positive role in the development of a society" in a (still unpublished) paper read at the Development Society's biennial conference, July 1988. In this development context Oosthuizen also briefly referred to the AICs. I will take seriously what he said on development in Africa, and the positive contribution the AICs is allegedly making.

Another foremost researcher in the field of AICs, M S Daneel, has lately 
written much (most of it yet to be published) on the involvement of the Fambidzano movement of Zimbabwe with development programmes. I was fortunate enough to make use of the final manuscript of his book on Fambidzano, in which he wrote one extended chapter (Chapter 8) about its development programme.

For the people attending this symposium ${ }^{3}$ the AIC movement is a speciality. But not much have thus far been written on the movement's relationship or contribution to development. So I will have to spend some time on the philosophy behind the term "development". Only then will it be worthwhile to explore the possibility whether the AICs have something substantially to contribute towards development.

\section{Turner}

Firstly, then, a resume of Turner's seminal thoughts. He starts off by acknowledging the fact that religions are generally conservative systems and as such more often than not obstacles to change. Development, to him, entails "change", and is synonymous with "modernisation", or, as he said: "... it might be better to speak of 'social transformation in the spirit of modernity' for 'traditional societies' ..."4. At other times he also uses the term "economic development" interchangeably with this.

"If we try to place the development issue, and all that goes with it, in the context of religion the problem, if anything, would seem to be increased. To link religions with development is to draw attention to the obstacles these great systems present through their own conservatism, their deep roots, fixed traditions and institutional inertia. While roots, traditions and conservation are essential in religions, what is an asset in this context readily operates as an obstacle when it comes to development in a spirit of modernity" ${ }^{\prime \prime}$.

Turning from the older religions to the New Religious Movements, and especially those in the primal societies, he says:

"We turn to these with some anticipation for they are not yet weighted with the conservatism and institutions of the older faiths, nor do they easily work in association with governments and so become involved in the concomitant restrictions"6.

The three significant features in which he thinks these new movements differ from the traditional religions from which they evolved, and which he finds "highly relevant to the modernization process" are: (a) their universal 
potential, (b) their innovatory capacity, and (c) their adjustments to more developed societies ${ }^{7}$. Nevertheless, the common reaction to these movements was usually negative because they were seen as "simply irrelevant or else as reactionary obstacles to real development, like the traditional or primal societies from which they spring". He however disagrees and gives a number of examples (from Black Africa) - the Apostles of John Masowe, the "Basketmakers" Church of Zambia, and the Harris Movement of West Africa - where there were clear development potential, but a potential which was sadly ignored by the authorities ${ }^{8}$.

Turner now ventures to mention three aspects of the world view of traditional societies that need to change if "development" is to occur. He is fully aware that these changes would actually mean an abandonment of the old world view (religion?), but sees no alternative.

* The first is the change "from magic and a sacralized world to science in a desacralized world". The "reliance upon the efficacy of magic as a causal agent is incompatible with realistic economic action for development". Nature should be desacralized. Only this makes "a scientific approach" (the legacy of the religion of ancient Israel) possible, which is a precondition for modern development ${ }^{9}$. This new world view makes possible an "individualization" and "responsibilization". 10

* The second change is that "from myth to historicized time". The old world view is essentially conservative, no changes are desired. Religion is concerned with regular renewal, but not with radical transformation. But all development involves changes. Turner sees the various miliennialisms, but also the ordinary achievements of the older churches and of the independents, and the varying eschatological emphases of churches, as signs of the coming new world view ${ }^{11}$.

* The third aspect is the change "from the closed, unitary, sacral society to the open, plural, secular society". The typical traditional cosmology and its associated mythology had the implication that the tribe, its rulers and institutions were set within a sacred cosmic order. Combined with the other aspects of the world view it inhibits any thought of a wider more inclusive society.

Turner finds definite signs that the African Independent/Indigenous Churches are contributing towards these changes: they " ... are increasingly absorbing the desacralized understanding of the world ..." 12 , and they "... are helping to achieve in one life-span the passage from a closed, sacral and unitary society to a modern secular state and religiously plural society"13.

"They have done this because they have been able to 
resacralize so much of the common life of their members within the context of the new religious community, with its own biblical mythology, charter and sanctions. This new community is a quite new social structure ... It is a radically different voluntary social form and so is part of the transformation from the old to the new, both in societies and world views". ${ }^{14}$

Apart from their contribution on the level of a new world view the AlCs also have achieved marked changes in the behaviour patterns of their members (even if not in the case of all their members) in certain key areas ${ }^{15}$ He again mentions three:

* New attitudes to work. It is well known that employers often prefer employees from certain independent churches because they regard them as good workers.

"People do tend to prosper when they join these groups, not only because of moral reform, health improvement, less wasteful spending practices, and regular habits built around the seven-day week programme of their new community, but also because of belief that they now have access to the power of the Spirit made available through these churches ... This encourages confidence, initiative, perseverance, adaptability to the changing modern situations and freedom from distraction through political or other hysterias"16.

* Better education and health. Especially in the field of health the AICs are very active. Turner says:

"There is also an increasing tendency to combine the independent spiritual treatment with the Western almost entirely physical treatment, and where this is done there is probably no better medical service available anywhere in Black Africa"17 $^{17}$.

* A new ethic with ascetic features ${ }^{18}$. In contrast to Asia, where the exemplary man is the one with the ideal of the ascetic life for himself and the simple life for all, in Black Africa the dominant image is that of the 'big man', an ideal which inhibits wholistic development. However, with many of the independent Church leaders we find a radically different, simple life style ${ }^{19}$. (He thinks that the general banning of the use of tobacco and alcohol is indicative of a certain ascetism, and has a more significant economic effect than it is usually given credit for ${ }^{20}$.) 
Turner acknowledges that there is another side to the story, and that disfunctional aspects also occur in these movements, but nevertheless he declares himself satisfied 'that the overall effect is very much on the credit side of the development ledger". He concludes:

"The special significance of these new religious movements lies in their influence and efforts being more spontaneous and locally generated, more indigenous in rationale, method and form, and in the kind of new order that is envisaged ... They represent a non-instrumental view of the relation between religion and development. ... to ask ... whether these new religious movements are a 'help or hindrance' to development implies too external a view of the relaticnship; rather is the kind of development we have surveyed integral to these movements' own existence ..." 21 .

I think it is necessary to enter into a discussion with Turner on his view of "development". He seems to operate with an already thoroughly discredited concept of development, namely "modernisation". The implication of having modernisation as goal for development is the acceptance that communities have only one hopeful way towards the future, and that may also be called "Westernisation". In crude form the practitioners of this view rush on and modernise the situation by bringing in modern developments on every level. People like Turner, who takes the wellbeing of the person as the measure of development success, and not the visible accomplishments of modernity, nevertheless sees a change of world view as necessary - a transition from the old cosmology to the secular one. If and when this change occurs, development is almost assured.

This idealisation of Western culture and economy is controversial, to say the least. On the one hand it cannot be denied that the achievements of the West are impressive. But, on the other hand, the applauded secularisation brought Western civilisation to the brink of moral collapse and religious indifference. The Western economic development also increasingly leads to not only a wider and deeper chasm between rich and poor, but its technology also contributes enormously to the systematic killing of our earth. No, we will have to search for something other than "modernisation" as goal for development.

However, I do think that Turner - especially in his concluding remarks which I quoted above - indicated an unease with the things he himself said. He mentioned the AIC's "non-instrumental view of the relation between religion and development" and that the kind of development which they represent are "integral to these movements' own existence". ${ }^{22}$ These thoughts I think, opened up meaningful avenues for further thought. 


\section{Oosthuizen}

I already mentioned Gerhardus C Oosthuizen's paper of 1985. He basically takes the same line as Turner, and in that sense my criticism applies also to Oosthuizen's reasoning ${ }^{23}$. However, he both expands and adapts Turner's theses and adds additional material from his ongoing research.

He starts off by taking an important stand on development in that he states clearly that the human factor should be regarded as basic. The acid test by which to gauge any theory or practice of development, he would seem to say, is the question: "what happens to the people involved?" This, I think, is the only acceptable Christian approach and the only sound foundation for development thinking.

But despite this promising beginning, in his subsequent reasoning "modernisation", "technological development" and "economic development" seems not only to be taken as meaning the same thing, but they are also fixed and final, almost inviolable values. He doesn't overtly entertain any thought that this type of development could be detrimental to mankind as a whole, or African humanity for that matter. Neither does he think about the metamorphosis these development processes may be required to accept in order to be healthy for and relevant to Africa. He only contemplates the changes that are required of the African human beings. Is that fair, especially in the light of his stated point of departure, namely that man is the centre of all development?

"The development that man requires is the kind that preserves his humanity, whilst at the same time enabling him to function within the context of the modern world..." ${ }^{24}$.

He also seems to fall in the same trap as Turner by believing in modernisation as the only possible way towards the future. So he uses the word "development" only in this sense, whether it is economical, political or human development that is meant.

"A people cannot develop economically, nor politically, if they themselves do not develop - that is, if they remain in an environment where the old value systems and attitudes to life prevail ${ }^{25}$.

Technological development, which he seems to regard as the (only) hope for Africa, does sometimes take place, but more often than not fails

"as a direct result of the tradition and culture of the people; the physical adjustments that such progress requires, often threaten the basic values and thought patterns of commu- 
nities.. .126 .

Development projects in Africa have failed, not in the first instance because the physical and economic changes that were brought about were inappropriate to the inner values of the people, but because the people were not ready for them.

"The main problem has not been the unsuitability of the systems imposed upon the African context - though this may be so in part - but the fact that such systems have not been transposed upon an adequately prepared foundation " 27 .

"... technological development cannot be thrust on a people who have not first gone through the appropriate human development which is as necessary for effective results in this field as in any other "28.

From that premise it logicalily follows that the "African soul" should be modernised. That is why he immediately (with Turner) commences the search for the necessary changes that must occur in the African soul in order to enable modernisation to set in ${ }^{29}$.

I quote at length from his 1987 article in order to illustrate his perceptive conclusions about what would have to happen if real modernisation is to occur in Africa.

'The word modern ... from the African point of view... must be understood as including: receptivity to new experiences...; readiness to accept social change...; tolerance of differences of opinion...; a high regard for efficiency; recognition of time as a valuable commodity...; and an orientation towards the future ...; acknowledgement of the important role of planning ...; usurpation of traditional fatalism...; development of educational and occupational aspirations and goals ...; and greater commitment to human dignity and human rights.

"In conclusion we can say that the following cultural changes need to be engendered: a movement away from a microcosmic to a macrocosmic perspective; a change in emphasis on vital force as the essence of being, to a more penetrating analysis of nature in terms of its potential for man ...; the need for traditional man to free himself from the community's hold...; a clear analysis of factors actively withholding the individual from creative adaptation...; the replacement of a consumption-orientated disposition towards Africa's resources 
by a creation-oriented disposition; the substituting ... of the "strong man" ideal with symbols that encourage progress and development...; a stripping away of traditional connotations from procreation...; the elimination ... of undue emphasis upon the past and utopian expectations of the future; the abandonment of current educational methods...; the placing of greater emphasis on the scientific and technological aspects of education; and avoidance of anything that emphasizes tribal loyalties ...". 30

In spite of my criticism of his approach, I cannot but acknowledge that Oosthuizen's argument is strengthened tremendously by his reference to the wider religious world, and especially the East. It is clear that the peoples of primal religions have a harder time to adapt to the modern world than those adhering to world religions. He finds the answer in the fascinating developments (the "enlightening") of the period 800 to $200 \mathrm{BC}$ to him "the most fruitful era in the moulding of man's intellect "131.

"The teachings of the great spiritual leaders, prophets and philosophers who emerged during this period, represent a change from mythic to self-reflective thinking, away from union with the cosmos and the tribe, and towards an individual identity that stands apart from nature and collectivity. Moreover, man adopted a new concept of time ....32.

Although it was among the people living in the "enlightened context" of the West that the scientific and technological revolutions of our age occurred, those in the East not only had very little difficulty in accommodating these changes (it must be remembered that much of the philosophies and mathematics underlying modern science were developed in the East), but they actually absorbed and utilised them so well that some of those nations seem to leave the Western nations behind in their progress ${ }^{33}$. On the other hand, those cultures who did not experience that "great outburst of creative activity" - and these include the traditional cultures of Africa - missed out on more than two thousand years of preparation ("enlightened thinking") for the coming of modernity. Oosthuizen warns:

"...if Africa fails to break free from the chains of primal thinking, in order to internalize a techno-scientific attitude towards its resources, this will remain a subservient continent ${ }^{34}$.

This certainly isn't a popular thing to say, but reflects the honest thinking of a sympathetic and concerned "African". He seems to say that Enemy Number One which retards the progress of Africa, and which may be held responsible for the further impoverishment and suffering of Africa, is none 
other than the tenacious primal world view.

Oosthuizen looks for a solution to this problem in two directions. In the first place he puts a high premium on education. Two quotes will give an indication of his views.

"... people must be encouraged and allowed to adjust their own thinking, values and culture through education" ${ }^{\prime 35}$

"Africa, therefore, does not need the kind of assistance that erodes self-respect and further discourages productivity... Rather, it requires constructive assistance in the form of mass training programmes in the technical, scientific and other appropriate fields. Imitation or assimilation is the only solution..." ${ }^{36}$.

\section{The AICs}

On the other hand Oosthuizen looks in the direction of the AICs, and there sees many hopeful things.

Whereas traditional or "mission" Christianity didn't yet seem able to play the constructive role in Africa which its parent bodies did in the development of modern Europe, there are signs that indigenous Christianity is indeed beginning to make its influence felt in this field:

"The findings of a research project ... undertaken in the African indigenous churches around metropolitan Durban ... revealed that not only did these people have a more advanced work philosophy than members of the historic churches, but ... that they had also adopted a modern attitude towards time ... Members also expressed their preference for modern ways above the older, more traditional ways, far more strongly than members of the established churches ..1137

In his 1988 paper Oosthuizen gave futher information on these findings and alludes to a number of changes in lifestyle following the changes in world view.

"In die AIC the individual ... has greater scope for development in that he is concerned about his/her own progress. The old fatalisms and traditional hierarchical structures have been overcome to a certain extent ..."

"According to the traditional world view nature cannot be 
controlled, but in the AIC they believe it is possible ..."

The standard of living as well as health conditions for many AlC members improved ..."

"Their emphasis is on a simple life and a definite democracy in sharing ... The income of these churches is largely used to assist needy fellow members. A healthy social and moral instinct reigns ..."

"Their world view has been inspired by emphases in the Bible ... for example, the emphasis on the future ..."

"Furthermore, the consumption emphasis of traditional Africa has been replaced by a more creative disposition ..."

"The personal psychic stress experienced in the traditional culture is alleviated by the AIC through their fellowships ... In these fellowships most of the fears, tensions, insecurities are overcome as well as ethnic and other prejudices....38.

These are to Oosthuizen signs that in the AICs a transition from the microcosmic into a macrocosmic world view is already taking place, and that would be - in terms of development - the greatest contribution anyone can make to the future of Africa.

\section{The AICs and development}

If we accept Oosthuizen's conclusions - and I would gladly do so - that there are many hopeful visible signs ("successes") of "development" among the AICs, the question may now be asked whether these examples do indeed support his hypothesis that modernisation in world view must be brought about for "development" to occur. Were the members of the AICs undergoing an intentional programme of modernisation? Or were the economically and socially positive developments merely "accidental" results of quite another programme, namely the inculturation and contextualisation of the Christian faith in people? Turner said something to that effect: the positive developments observed in the movement is less the result of external initiative than inner dynamics ${ }^{39}$.

The AICs were usually (and still are today) criticised exactly because they are too little involved in an intentional programme of world view change. To our liking we hear too little of a Barthian "Nein!" to "paganism", and consequently are afraid that the continuity with the traditional thought forms and behaviour patterns may lead them back to pre-Christendom. We tend to accuse them of syncretism. Instead of setting out to change the 
people's way of thinking, they accommodate as much as possible of the traditional. But nevertheless their "development successes" are evident! It makes one think.

It would probably be worthwhile to study the development effect of the message preached in these Churches, but I would submit that the real key may be the new community (koinonia) found in these groups. I'm beginning to think that the AlCs - just as other "base groups" in the church worldwide - are opening up a dimension of "development" which may represent a break-through (a paradigm change) in this field.

Real development, I think, comes "from below", from the base, the grassroots. When the life-giving power of the Holy Spirit starts working in a community with their feet on the ground and their arms around each other, real development - call it transformation if you will, or liberation, or regeneration for that matter - may happen. When this koinonia, fellowship with God and with each other, are lacking, the results are stultified, unbalanced, tend to be selfish, even destructive. That is no development in the sense which we would like to speak of it.

This may sound very "evangelical", as I intended it to be. But the effect of "good news" values in the cases of basic Christian communities (such as the AICs and BCCs ${ }^{40}$ of Latin America and Africa) are too evident to be missed.

\section{Daneel}

When we turn to the work of Inus Daneel we know what to expect: not theorising, but the relating of a wealth of data about the Indigenous Churches among the Shona of Zimbabwe. In this paper I will exclusively refer to his (forthcoming) book which tells the story of Fambidzano, the Conference of AlCs which he himself was instrumental in bringing into being, and which he still serves in a honorary capacity ${ }^{41}$. In the past few years Fambidzano has embarked on "development work", so it is especially this dimension that deserves our attention. In this sense the Fambidzano story is another example in the category of those which Turner referred to in his paper. In this following section we will therefore look at the efforts of a group of AlCs to become engaged in the practical aspects of development (or "progress", as Daneel calls it ${ }^{42}$ ).

Daneel reminds us of "the threefold objectives of Fambidzano: ecumenical advancement, theological training (and spiritual renewal) and material progress through development ${ }^{\prime 43}$. Of these the first two were the original and are unnegotiable. Chapter 8 of this book is in fact relating the arduous process of developing the third emphasis, without endangering the ori- 
The involvement of Fambidzano in the area of development commenced with the forming of a development committee. Overseas sponsoring made it possible to rent offices, purchase a vehicle, and appoint development officers and staff ${ }^{44}$. The development activities initially touched on five areas: education, agriculture, the building of community halls, water development, and small-scale community projects ${ }^{45}$. It was especially the building projects that were popular. It may be criticised as too prestigeoriented, but Daneel points out that it in fact entailed much more than that. In these Churches "Church life, agriculture and education form integral components of a single system. It is a mutual-aid system, beneficial in various degrees to all participants" ${ }^{\prime \prime}$.

At least four factors caused Fambidzano - after more than a decade of involvement in ecumenical and theological training - to engage in development work.

* In the first instance the bishops had for a long time yearned for rural advancement, but up to that stage they had failed to improve their own economic position through Fambidzano ${ }^{47}$.

* Secondly. "Once political independence had been achieved agricultural and rural development were in the air. Everybody spoke about it and everybody was eager to contribute to and benefit from the scores of government and overseas-sponsored development projects". 48

* Although many Independents were involved as individuals in the cooperatives of their communities they increasingly required projects which they themselves as church groups could control ${ }^{49}$.

* "Moreover, the successes of the Rev. Zvobgo and Bishop Nehemiah Mutendi in raising funds and building schools at their Church headquarters strengthened the development expectations and plans of rural IC bishops".

The introduction of a development programme brought drastic and sometimes traumatic changes to the Conference. On the one hand its membership doubled because of the recruitment value of the projects. But on the other hand there arose an "intense internal conflict involving constitutional change and radical, if unsettling reform of financial management which threatened the entrenched position of the TEE college and thereby the entire existence of the Conference ${ }^{151}$. Another cause of concern, Daneel thinks, is the "unwillingness of Independent Church leaders to consider seriously at this early stage the long-term implications of the use of foreign 
funds ${ }^{152}$. They not only seem to think that overseas funds will remain available for ever, but they also show an inclination to the unfortunate opinion that they are victims of colonial exploitation and that things could only be redressed when the West gave back what they took. This certainly indicates a kind of blind spot in the development programme.

It is clear that there is illustrated the very real risk of materialistic considerations corroding the true objectives of Fambidzano. Nevertheless, Daneel does think that on balance the direct involvement in development work is beneficial to the Conference ${ }^{53}$. Apart from the fact that it brought about closer links with affiliated Churches, a higher profile among the communities and with the government than before ${ }^{54}$, and intensified interaction between Fambidzano and the Zimbabwe Christian Council; even more positive is the fact that the responsibility which the recipient churches had to take for their projects "has moved both leader and followers to a deeper commitment to social development than before ${ }^{\prime 155}$ and brought into practice the concept of mutual aid between the Conference's member Churches $^{56}$. Furthermore, although Fambidzano's development programmes are not actively and overtly promoting female emancipation through a process of rapid and radical reform, yet a subtle process of transformation is in fact taking place through rural projects ${ }^{57}$. And, last but not the least, there seems to be a positive correlation between development work and Church expansion ${ }^{58}$.

To those who criticise the Independent Churches as being backward and obstructing the processes of modernization and Zimbabwean socialism, Daneel has this to say:

"On the contrary, their members are involved in quite a number of rural co-operatives ... Moreover, they are convinced of the positive functions they are capable of fulfilling in the future of Zimbabwe; they are not lingering in the protests of yesterday; and, ... they themselves are fast becoming ... the progressive agents of change and modernization" ${ }^{59}$.

It is important to enquire whether there already is a theology or philosophy of development that can be discerned. Daneel thinks the one and

"dominant theological theme in the development activities is 'salvation here and now' ... It is an incarnational theology in which the compassion and grace of God becomes concretely visible. It understandibly has materialistic overtones. At the same time it strengthens spirituality and inspires renewal and fresh hope of a better quality of life and increased church growth", 
Material progress "would make a reality, more palpable than before, of present wellbeing, of salvation here and now by the benevolent God"61.

The beginnings of a "theology of progress" can be seen in the telling words of one of the leading Independents, Rev. Zvobgo:

"In teaching the Independents I compare them with John the Baptist and Jesus. John ate locusts and honey, as he lived out in the desert. Jesus, on the other hand, entered the houses of people where he received goats and other food to live on. He even had his own treasurer, Judas. I tell these Church leaders to change from being a John of the desert to Jesus who entered houses. I tell them: 'Change, so that our Churches can progress!" 62 .

Daneel feels that there is a dire need for further theological reflection on their development activities. Such a design would have to (a) stipulate the conditions of sponsorship, (b) be closely linked to the creation of a thinktank of IC experts, and (c) be undergirded by a properly defined ideology, or what could be described as a theology of development and progress. This last would have to incorporate, amongst other things, statements to the effect that:

* development work is aimed not only at the economic progress of individual persons and/or Churches but at the advancement of society and the environment ...;

* development projects should serve the poor in society;

* progress implies the elimination of exploitive structures which permit an IC leader or a select group of his/her relatives to benefit disproportionately in comparison with the actual labour force;

* progress therefore involves an equitable distribution of newly created work opportunities and benefits;

* the interaction between a socialist state and the Churches in this field should be defined ${ }^{63}$.

This last is clearly a first sketch of Daneel's own design for a theology of development. But we must keep in mind the extent to which his theology and that of the Independents have become one. He not only studies them, but is involved with them.

That is why his latest dream for the Independents is so significant. He 
thinks they should become involved - together with the traditional "spirits" and the mission Churches - in an ecological ministry and an all out drive to "save the land". We hear him spell it out:

"The basic motivation behind Fambidzano's development work so far has been the socio-economic advancement of its member Churches. This makes a much needed and constructive contribution considering the large representation of poor and underprivileged rural inhabitants in the Independent Churches. Development work, however, takes place in an environment whose natural resources are consistently abused through population pressure, deforestation, overgrazing, etc ... Development and progress presuppose a protected and healthy environment ... Once the Conference moves beyond the present development goals of immediate material progress for its Churches, it is bound to find itself confronted with this, the most formidable but also the most exciting challenge it has yet faced"64.

I totally agree with these sentiments. As a matter of fact, I think that Daneel has here touched the core of the development debate: no so-called development effort is worthy of the name when the ecological integrity of creation is impaired. Further, every development programme should actively work for the "shalom" (peace) of all creation. If the development involvement of the AICs will incorporate this, it may well provide the development model for Africa.

We do not here have the time or space to pursue this notion, but it should be done. According to Daneel this challenge will require a threefold response:

(i) At the ideological level a viable theology of the environment should be worked out. Existing theological trends in the Independent Churches ... could be reinterpreted ...

(ii) ... an information service and conscientization programme will be needed ...

(iii) ... theologizing and conscientization will have to be concretely expressed in properly planned programmes of ac-
tion"65 
1. Published in Frederick Ferre \& Rita H. Mataragnon (eds), God and global justice: Religion and poverty in an unequal world, New York 1985. I will quote from the unpublished text of the speech.

2. The Africa Institute regarded it of such importance that they twice published it, first in the Special Jubilee Edition of their Journal of Contemporary African Studies, October 1985, 77-113, and then in Africa Insight 17 (1987), 107-120. My quotations will be from the latter published version.

3. This paper was read at the symposium of the Research Unit for New Religious Movements and Indigenous Churches (NERMIC), on the 28th of June 1989, at Unisa.

4. Turner, op. cit., 1.

5. ibid.

6. op. cit., 2.

7. op. cit., 4.

8. op. cit., 5-6.

9. op. cit., 7.

10. op. cit., 8.

11. ibid.

12. op. cit., 7 .

13. op. cit., 9 .

14. op. cit., 10.

15. We may here quote the conclusion of Martin West in a paper where he gave attention to the AlCs and poverty: "For while we have seen that the independent churches have various strategies for combating poverty, a much more important and positive role is an attempt to create for their members a more satisfactory quality of life than they might experience in some mission churches, and, a fortiori, in the secular world outside". Martin West, "Poverty and relative deprivation in African Independent Churches", in K. Nürnberger (ed.), Affluence, poverty and the Word of God, Durban 1978, 245.

16. op. cit., 11.

17. op. cit., 13.

18. Here we may also refer to the article of J P Kiernan, "Poor and puritan", African Studies 36 (1977), 31-41. In this he indicated ways in which the Zionists of the Durban area were combating poverty.

19. op. cit., 13.

20. op. cit., 14.

21. op. cit., 16.

22. op. cit, 16.

23. In this criticism I am not alone. C J Maritz, in a response to Oosthuizen's paper, puts it thus: "Although Prof Oosthuizen does not define what he understands under "development", it is implied in his article that development is seen as a unilinear process with a universally accepted goal ... in line with the 1960 s theory known as the 
"modernization" approach: identify the values which retard "development", change them - and the target community is on its way to becoming similar to the modern (Western) model ... Experience over the past three decades has ... shown that we should, first, distinguish between modernization and development as concepts and that, secondly, modernization should be discarded as a teleological theory for the upliftment of the Third World". C J Maritz, "Africa's social and cultural heritage in a new era", Africa Insight 17 (1987), 120-121, 139. (Quote from page 121)

24. G C Oosthuizen, "Africa's social and cultural heritage in a new era", Africa Insight 17 (1987), 107.

25. ibid.

26. op. cit., 108.

27. op. cit., 119.

28. op.cit., 108.

29. See also G C Oosthuizen, "Religion, its negative and positive role in the development of a society". (Still unpublished paper read at the Development Society's biennial conference, July 1988, 9.) Here Oosthuizen identified "issues in African traditional religion and culture that retard development", namely 1) too high level of group consciousness, 2) lack of planning, 3) dependence on nature as the providing mother, and 4) the reign of mysterious 'power'.

30. op. cit., 119.

31. op. cit., 109.

32. op. cit., 110.

33. ibid.

34. op. cit., 112.

35. op. cit., 108.

36. op. cit., 116.

37. op. cit., 117.

38. op. cit., 1988, 9-10.

39. op. cit., 16.

40. I refer to my article (and the published material to which I referred) on "The base movement as a model of 'development'" in Missionalia 17 (April 1989), 31-44.

41. Thanks to Daneel I was able to make use of a set of the final proofs of the forthcoming book. The page numbers, as referred to, are therefore correct.

42. M L Daneel, Fambidzano. Ecumenical movement of Zimbabwean Independent Churches. Gwelo (in process) 1989, 455, 463, 506.

43. op. cit., 455.

44. op. cit., 432.

45. op. cit., 434-448.

46. op. cit., 436.

47. op. cit., 417.

48. op. cit., 418. 
49. ibid.

50. ibid.

51. op. cit., 424, 450.

52. op. cit., 486.

53. op. cit., 447.

54. op. cit., 467.

55. op. cit., 441.

56. op. cit., 468 .

57. op. cit., 475.

58. op. cit., 479.

59. op. cit, 519.

60 . op. cit., 471.

61. op. cit., 417.

62. op. cit., 463.

63. op. cit., 506.

64. op. cit., 507.

65. op cit., 507-512. 